\title{
Hodnocení návrhu produktu s ohledem na jeho souhrnné funkce
}

\author{
Tomáš Broum ${ }^{1}$ \\ 1 Západočeská univerzita v Plzni, Fakulta strojní, Katedra průmyslového inženýrství a \\ managementu \\ Univerzitní 8, 306 14, PIzeň, Česká republika \\ broum@kpv.zcu.cz
}

\begin{abstract}
Anotace: Tento príspěvek představuje nový koncept souhrnných funkcí a jeho použití prì návrhu produktu a jeho hodnocení. První část príspěvku se soustředí na koncept souhrnných funkcí produktu. Jsou zde popsány dva pohledy na funkce, tedy pohled výrobce a pohled zákazníka, jejich kombinací jsou pak získány př́slušné souhrnné funkce produktu. Druhá část príspěvku se pak zaměřuje na návrh produktu, který využívá koncept souhrnných funkcí a následně na hodnocení produktu po stránce naplnění technických požadavků. Poslední část příspěvku je zaměřena na předkalkulaci a z ní vyplývající hodnocení nákladovosti.
\end{abstract}

\section{1 Úvod}

Nejdůležitější fází životního cyklu produktu ovlivňující náklady na produkt je fáze jeho návrhu. $V$ této fázi je ovlivněna většina nákladů na produkt. Náklady zde mohou být ovlivněny výrazněji než ve fázi výroby. [1] Samotnému návrhu předchází definice základních charakteristik produktu, po které následuje analýza trhu, zákazníků, konkurence, na tyto oblasti se príspěvek nezaměřuje a soustředí se až na následující fázi, tedy analýzu funkcí produktu, ze které konkrétní návrhy produktu vychází. Zde je pak představen koncept souhrnných funkcí produktu. Návrhy produktu je samožrejmě nutné ohodnotit a zvolit ten, který je vhodný pro detailní rozpracování. Hodnocení jednotlivých návrhů po stránce naplnění technických parametrů a nákladovosti se zabývá zbytek př́spěvku.

\section{Analýza funkcí produktu}

Časté členění funkcí v literatuře o metodě Target Costing [2] je na tvrdé a měkké funkce.

- Tvrdé funkce - funkce nezbytné pro základní funkčnost produktu, pro splnění základních požadavků na produkt. Příkladem mohou být brzdy $u$ automobilu.

- Měkké funkce - funkce, které produkt mít nemusí, ale zákazník je požaduje. Jedná se např. o luxusní vzhled vozu. 
Tento pohled na funkce odpovídá členění funkcí v rámci hodnotové analýzy [3] na funkce vázané $k$ užitné hodnotě a funkce vázané k osobní oblibě.

Další rozdělení funkcí, ve kterých jsou určitým způsobem tvrdé a měkké funkce obsaženy je rozdělení na:

- Funkce produktu z pohledu výrobce

- Funkce produktu z pohledu zákazníka

Funkce produktu z pohledu výrobce zahrnují zejména funkce umožňující produktu pracovat, tedy ty funkce, které zákazník považuje za samozřejmé. U funkcí produktu z pohledu zákazníka jsou podstatné takové funkce, které vnímá zákazník jako důležité, ty velmi ovlivňují prodejnost produktu.

Zjednodušeně by se tedy mohlo zdát, že funkce z pohledu výrobce odpovídají tvrdým funkcím a funkce z pohledu zákazníka měkkým funkcím. Skutečnost je však taková, že funkce z pohledu výrobce obsahují tvrdé i měkké funkce $s$ převahou funkcí tvrdých. Funkce z pohledu zákazníka obsahují měkké a tvrdé funkce, kdy převažují funkce měkké. Tedy obě kategorie jak funkcí z pohledu zákazníka, tak funkcí z pohledu výrobce, obsahují oba typy funkcí tvrdé i měkké, ale $v$ jiném poměru.

Dále se $v$ článku pracuje s pojmy funkce produktu $z$ pohledu výrobce a zákazníka, protože to více odráží povahu funkcí, jak jsou v dalším postupu používány.

Pojmem souhrnné funkce produktu jsou pak nazývány výsledné funkce, po propojení pohledů na funkce produktu z pohledu zákazníka a výrobce. Tento nový přistup $\mathrm{k}$ funkcím zavádějící pojem souhrnné funkce produktu má ten důvod, aby pomocí propojení obou pohledů na funkce $z$ hlediska výrobce a zákazníka byl získán jediný pohled dostatečně respektující oba zmíněné pohledy. Ze souhrnných funkcí produktu se pak vychází i v dalším postupu.

\subsection{Analýza funkcí produktu z pohledu výrobce}

Pro stanovení funkcí z pohledu výrobce je použita specifikace požadavků na daný technický produkt / systém s hodnocením a analýzami jejich splnění včetně indikace rizik (zkrácené pojmenování: specifikace požadavků na produkt) vycházející z teorie technických systémů. Volba pro její použití v navrhované metodice je $z$ důvodu jejího vývoje a použivání na Katedře konstruování strojů ZČU v Plzni, kdy odborníkem z této katedry bylo doporučeno její použití v této práci.

Původním účelem specifikace požadavků na produkt je doplnění a vyjasnění zadání úkolu pro konstrukční oddělení. Výstupem jsou pak vlastnosti produktu, které jsou jinak nazvanými funkcemi produktu z pohledu výrobce.

Specifikace požadavků na produkt může vycházet z informací [4]:

- Analýzy State of the Art (stavu techniky)

- Z předpisů, norem, apod. 
- Z požadavků trhu/zákazníka

- $\quad Z$ interních rozhodnutí organizace

Postup při tvorbě specifikace dle zmíněné metody s využitím softwarové podpory se skládá $z$ následujících kroků [4]:

1. Zadání základních údajů o projektu navrhovaného technické systému

2. Specifikace tržních 'Product-Business' požadavků na technický systém

3. Specifikace konstrukčních 'Product-Design' požadavků na technický systém

4. Hodnocení a analýzy konstrukčního splnění 'Product-Business' požadavků na technický systém

5. Hodnocení a analýzy konstrukčního splnění 'Product-Design' požadavků na technický systém

Výstupem je vlastní specifikace požadavků na produkt ve formě stanovených funkcí produktu z pohledu výrobce a jejich vah důležitosti. Součástí výstupu je i hodnocení produktu, dle různých hledisek.

Příklad části specifikace požadavků na produkt s využitím softwarové podpory je uveden na obrázku 1.

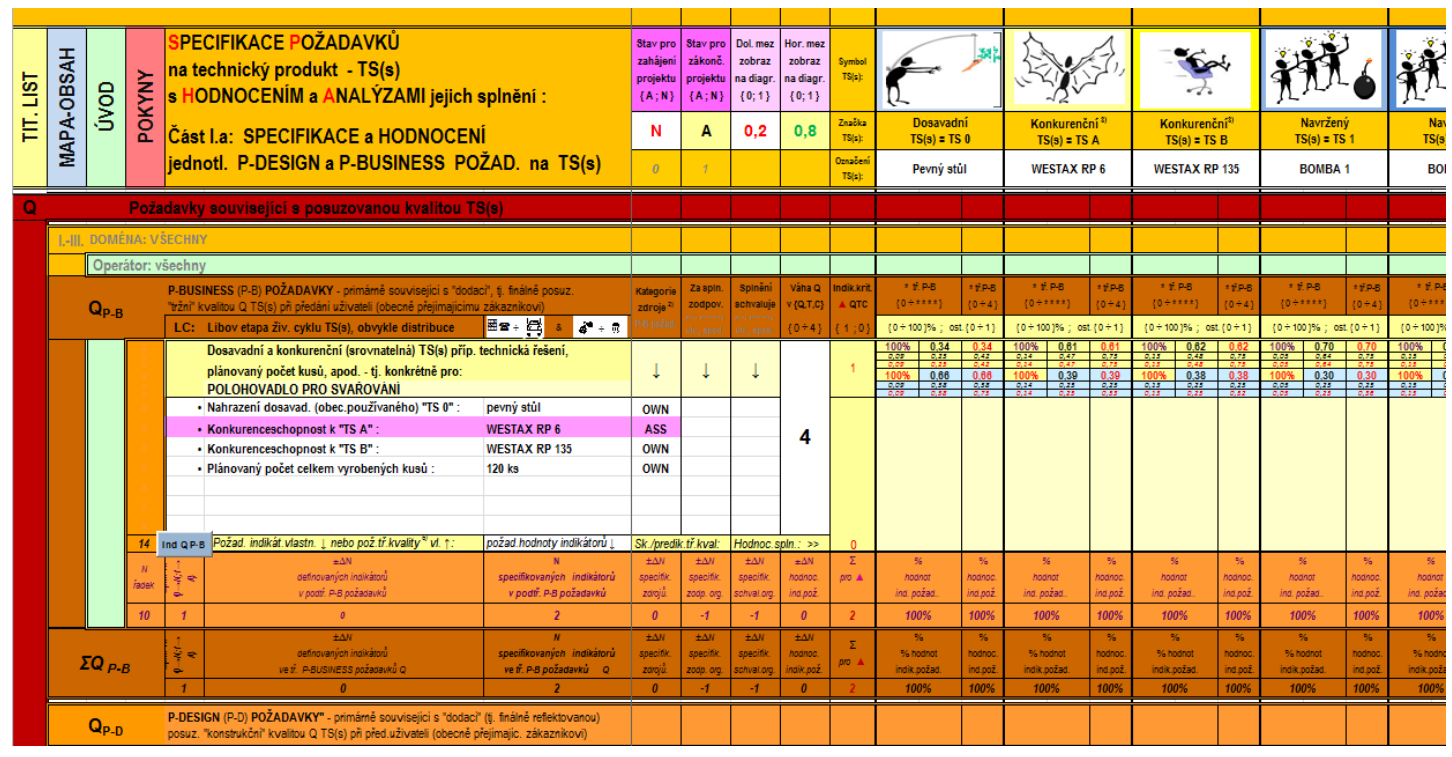

Obrázek 1 - Přiklad specifikace požadavků na produkt - softwarová podpora [5]

\subsection{Analýza funkcí produktu z pohledu zákazníka}

Stanovení funkcí produktu z pohledu zákazníka a jejich užitnosti je nutné pro stanovení souhrnných funkcí produktu, které jsou vstupem pro morfologickou analýzu, z níž vychází návrh produktu.

Navrhovaný postup stanovení funkcí z pohledu zákazníka vychází z marketingového výzkumu mezi potenciálními zákazníky (uživateli). Výsledek 
je pak vyhodnocen a výstupem je stanovení funkcí produktu z pohledu zákazníka a jejich užitku pro zákazníka.

Z analýzy produktu jsme získali základní informace o produktu. Je znám i zákaznický segment, na který je vhodné se zaměřit. Nyní je tedy možné se soustředit na konkrétní funkce produktu z pohledu zákazníka a stanovit jejich užitnost.

Vhodnou metodou $v$ rámci marketingového výzkumu pro zjištění funkcí produktu z pohledu zákazníka je dotazníkový průzkum, protože smyslem je získat konkrétní odpovědi od většího množství potenciálních zákazníků. Ten může být prováděn at' již $v$ elektronické, tak $v$ papírové podobě. Na základě dotazníkového průzkumu jsou zjištěny funkce produktu z pohledu zákazníka (a to včetně jejich užitnosti) týkající se zejména měkkých a z části i tvrdých funkcí. Měkké funkce jsou respondenty často zdůrazňovány, protože tvrdé funkce považují za samožrejmost. Dotazníky od jednotlivých respondentů se vyhodnotí a stanoví se nejvýznamnější funkce produktu z pohledu zákazníka.

Výstupem analýzy funkcí z pohledu zákazníka je tedy stanovení funkcí produktu z pohledu zákazníka včetně stanovení jejich užitnosti. Tento výstup je spolu $s$ výstupem $z$ analýzy funkcí z pohledu výrobce propojen v následujícím kroku (podkapitole).

\subsection{Vytvoření souhrnných funkcí}

Aby mohly být co nejlépe naplněny požadavky zákazníků při současném respektování požadavků výrobce, je nutné vhodně stanovit funkce produktu, ze kterých bude vycházet jak konstrukční oddělení při jeho návrhu, tak oddělení controllingu prí kalkulaci nákladů. Ze softwarového zpracování specifikace požadavků na produkt jsou získány nejvýznamnější funkce produktu z pohledu výrobce a vyhodnocením dotazníků od vybraných respondentů nejvýznamnější funkce z pohledu zákazníka. Propojení těchto dvou pohledů na funkce budoucího produktu a vyplývající stanovení souhrnných funkcí produktu je cílem tohoto kroku.

Postup stanovení souhrnných funkcí produktu je následující. Nejprve jsou porovnány funkce $z$ jednotlivých pohledů s ohledem na duplicity, kdy jsou funkce podrobně prozkoumány za spolupráce konstrukčního oddělení a oddělení marketingu a odstraněny funkce duplicitní. Výstupem je jedna tabulka s funkcemi, u které je nutné provést přepočet užitnosti.

\section{Návrh produktu}

$\mathrm{Na}$ základě vydefinování produktu a stanovení jeho souhrnných funkcí je provedena druhá fáze navrhovaného postupu. Tato fáze se zabývá návrhem jednotlivých variant produktu, tvorbou jednotlivých koncepcí (hrubých stavebních struktur) produktu. Při stanovení variant koncepcí je využito morfologické analýzy, která umožňuje prozkoumat, co největší širíi možných koncepcí. Tyto varianty jsou následně i ohodnoceny, kdy toto hodnocení je 
provedeno po stránce naplnění technických požadavků na produkt. Hodnocením po nákladové stránce je otázkou následujících fáze (kapitoly).

\subsection{Morfologická analýza}

$\mathrm{K}$ tvorbě variant návrhu produktu je vhodnou metodou Morfologická analýza, která: „systematicky identifikuje všechny možnosti řešení problému přes jednotlivé atributy a spojuje je do různých kombinací pro vznik ideálního řešení“ [6].

Základem morfologické analýzy je morfologická matice, ve které jsou v prvním sloupci vyjmenovány jednotlivé souhrnné funkce produktu a $v$ dalších sloupcích jsou k těmto souhrnným funkcím stanoveny nositelé funkcí. Nositel funkce ukazuje možné naplnění souhrnné funkce pomocí určitého funkčního principu či pomocí konkrétního orgánu (strojní části). Využít Ize metody brainstormingu, kdy se team konstruktérů snaží ke každé souhrnné funkci stanovit maximální počet nositelů funkcí.

Po stanovení morfologické matice je vybrán první nositel funkce u jednotlivých souhrnných funkcí a posouzena realizovatelnost této varianty návrhu. Následně se prochází jednotlivé kombinace nositelů a posuzuje se realizovatelnost jednotlivých variant návrhů. Cílem je prozkoumat všechny kombinace a zvolit realizovatelné návrhy.

Výstupem prvního kroku druhé fáze navrhovaného postupu je morfologická matice obsahující 3 návrhy (koncepční schémata), viz. tabulka 1. Tato schémata jsou znázorněna jednotlivými barevnými čarami $v$ morfologické matici.

Tabulka 1 - Morfologická matice včetně návrhů [Zdroj: autor]

\begin{tabular}{|l|c|c|c|c|c|c|c|}
\hline \multirow{2}{*}{ Souhrnné funkce } & \multicolumn{7}{|c|}{ Funkční principy a př́slušné orgány - nositelé funkcí } \\
\cline { 2 - 8 } & 1 & 2 & 3 & 4 & 5 & $\ldots$ & \multicolumn{2}{c|}{$\mathrm{m}$} \\
\hline Souhrnná funkce 1 & Nositel . funkce 1 & Nositel 2 funkce 1 & $\ldots$ & $\ldots$ & $\ldots$ & $\ldots$ & Nositel $\mathrm{m}$ funkce 1 \\
\hline Souhrnná funkce 2 & Nositel 1funkce 2 & Nositel 2 funkce 2 & $\ldots$ & $\ldots$ & $\ldots$ & $\ldots$ & Nositel $\mathrm{m}$ funkce 2 \\
\hline Souhrnná funkce 3 & $\ldots$ & $\ldots$ & $\ldots$ & $\ldots$ & $\ldots$ & $\ldots$ & $\ldots$ \\
\hline Souhrnná funkce 4 & $\ldots$ & $\ldots$ & $\ldots$ & $\ldots$ & $\ldots$ & $\ldots$ \\
\hline Souhrnná funkce 5 & $\ldots$ & $\ldots$ & $\ldots$ & $\ldots$ & $\ldots$ & $\ldots$ & $\ldots$ \\
\hline Souhrnná funkce 6 & $\ldots$ & $\ldots$ & $\ldots$ & $\ldots$ & $\ldots$ & $\ldots$ & $\ldots$ \\
\hline Souhrnná funkce 7 & $\ldots$ & $\ldots$ & $\ldots$ & $\ldots$ & $\ldots$ & $\ldots$ & $\ldots$ \\
\hline & $\ldots$ & $\ldots$ & $\ldots$ & $\ldots$ & $\ldots$ & $\ldots$ & $\ldots$ \\
\hline Souhrnná funkce $\mathrm{n}$ & Nositel 1 funkce $\mathrm{n}$ & Nositel 2 funkce $\mathrm{n}$ & $\ldots$ & $\ldots$ & $\ldots$ & $\ldots$ & Nositel $\mathrm{m}$ funkce $\mathrm{n}$ \\
\hline
\end{tabular}

\subsection{Stanovení hrubých stavebních struktur vybraných variant}

Nyní je provedeno hrubé rozpracování těchto návrhů do hrubých stavebních struktur (koncepcí). Stavební strukturu Ize definovat následovně: stavební struktura je reálná struktura technického systému - produktu odpovídající výrobě a montáži technického systému z hierarchicky uspořádaných stavebních prvků (součástí/dílů, montážních skupin, ...) [4]. 
Součástí tohoto hrubého rozpracování je popis hrubé stavební struktury včetně prvotního designového návrhu. $V$ popisu hrubé stavební struktury musí být uvedeny[4]:

- $\quad$ součástí/díly produktu (tech. systému) a jejich vazby (uspořádání)

- $\quad$ pro jednotlivé prvky stavební struktury (součásti a díly): tvary, rozměry, materiály, způsoby výroby, stavy povrchů, odchylky od jmenovitých hodnot

Prvotní designový návrh je konkrétním zobrazením hrubé stavební struktury. Je možné jej provést klasicky pomocí tužky a papíru či s využitím počítačové podpory. To je provedeno u všech vybraných variant. Př́klad designového návrhu je uveden na obrázku 2.

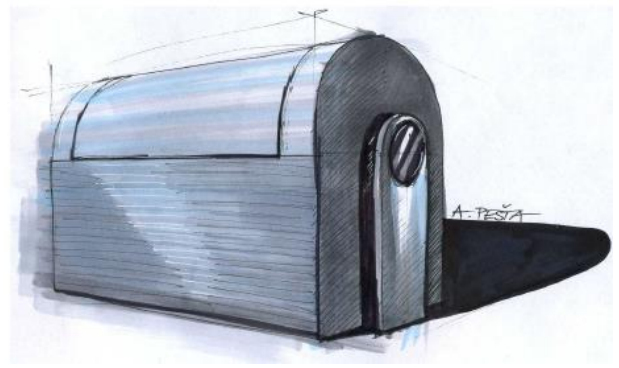

Obrázek 2 - Přkiklad designového návrhu průmyslové myčky součástí [7]

\subsection{Hodnocení variant návrhů produktu}

Hodnocení je provedeno po stránce naplnění technických požadavků na produkt. Hodnocení po nákladové stránce je otázkou následující fáze postupu.

Hodnocení technických požadavků probíhá dle následujícího postupu:

1. Stanovení vah souhrnných funkcí

Pro určení významnosti souhrnných funkcí, Ize využít dříve stanovenou užitnost u jednotlivých souhrnných funkcí.

2. Bodové ohodnocení naplnění funkcí jejich nositeli

$\checkmark$ rámci hodnocení návrhů variant produktu jsou zkoumány jednotlivé souhrnné funkce a u nich ohodnoceno jejich naplnění nositeli. Využita je desetistupňová stupnice, pro dostatečnou rozlišovací schopnost. Hodnocení je vhodné provádět teamově a zprůměrovat jednotlivé hodnoty.

3. Vážené bodové hodnocení

Nyní se provede vynásobení získaných bodových hodnot $\mathrm{s}$ váhami. Výsledkem je vážené bodové hodnocení.

4. Výsledné pořadí produktů

Pořadí variant se stanoví pomocí poměrného hodnocení, kdy se celkový součet bodů hodnocení konkrétní varianty vydělí celkovým součtem 
hodnocení ideálního produktu. Přičemž nejvyšší hodnota určuje nejlepší variantu z hlediska naplnění technických požadavků.

Výstupem této fáze jsou tedy 3 návrhy produktu - koncepce, se stanovenou významností z hlediska naplnění technických požadavků. Tyto varianty jsou následně pomocí předkalkulace nákladově ohodnoceny.

\section{Předkalkulace - stanovení nákladů variant návrhů produktu}

Po zhodnocení jednotlivých variant a zjištění, zda odpovídají požadavkům z hlediska technických parametrů, je třeba zjistit nákladovost těchto variant, nebot' ta je odlišná podle zvolených nositelů funkcí. Z toho důvodu jsou ve třetí fázi stanoveny náklady zvolených variant. Pro zjištění nákladů jednotlivých variant je provedena předkalkulace na bázi úplných nákladů, a to konkrétně pomocí metody: diferencovaná přirážková kalkulace. Kalkulaci na bázi procesních nákladů, která je přesnější, není možné v této fázi použít, protože návrh produktu ještě neobsahuje konkrétní výrobní procesy, aby tato kalkulace mohla být aplikována. Diferencovaná prírážková kalkulace je pro toto hodnocení dostatečně přesná.

Nyní je pro jednotlivé varianty produktu provedena předkalkulace dle metody diferencované přirážkové kalkulace. Vychází se z typového kalkulačního vzorce uvedeného na obrázku 3.

$$
\begin{aligned}
& \text { Přimý materiál } \\
+ & \text { Režijní materiál } \\
= & \text { Materiál celkem } \\
+ & \text { Přmé mzdy } \\
+ & \text { Výrobní režie } \\
= & \text { Vlastní náklady výroby } \\
+ & \text { Správní a odbytová režie } \\
= & \text { Uplné vlastní náklady }
\end{aligned}
$$

Obrázek 3 - Typový kalkulační vzorec

Pro hodnocení nákladovosti variant je důležité, že tato metoda pracuje s více režijními přirážkami, zpravidla zvláštní přirážka pro každou oblast režijních nákladů podle kalkulačního vzorce. Režijní přirážky se použijí takové, které jsou u výrobce obvyklé pro podobný produkt. Pokud podobný produkt nevyrábí, pak použije obvyklé přirážky použivané u jiných produktů, či jejich prưměr. Vlastní výpočet kalkulace nákladů probíhá do úplných vlastních nákladů.

Výstupem této fáze jsou tedy úplné vlastní náklady jednotlivých variant. Ty jsou pak následně porovnány. Jedná se o prosté porovnání z hlediska absolutní velikosti nákladů. Minimalizační kritérium určuje výsledné pořadí 
variant $\mathrm{z}$ hlediska nákladů. Tímto je zjištěna nejvýhodnější varianta z hlediska nákladů.

\section{Závěr}

Současné pohledy na funkce preferuji pohled výrobce či pohled zákazníka, což může vést $\mathrm{k}$ návrhu produktu, který nerespektuje jeden $z$ těchto pohledů. Příspěvek popisuje koncept souhrnných funkcí produktu, jehož výhodou je zahrnutí obou těchto prístupů. Tento koncept je dále využit pro návrh vlastního produktu, který následně může lépe naplňovat požadavky výrobce $\mathrm{i}$ zákazníka. V rámci samotného návrhu je nezbytné variantní řešení, které následně vyžaduje příslušné varianty ohodnotit, což je podstatný podklad pro výběr vhodné varianty pro následné detailní rozpracování zvolené varianty produktu. Toto hodnocení, jak po stránce naplnění technických parametrů respektující souhrnné funkce, tak po stránce nákladovosti jednotlivých variant, je také součástí tohoto príspěvku.

\section{Poděkování}

Tento článek byl vytvořen za podpory interního grantu Západočeské univerzity číslo projektu je SGS-2018-031 s názvem Optimalizace parametrů udržitelného výrobního systému.

\section{Použitá literatura}

[1] Broum, T., Dvorak, J., Kleinova, J. Value Optimization and Risks Elimination of Product. In: Annals of DAAAM for 2011 \& Proceedings of the 22th international DAAAM symposium. Vienna, Austria, 2011, p. 757-758. ISBN 978-3-901509-83-4.

[2] The Society of Management Accountants of Canada, Implementing Target Costing [online] Montvale: Institute of Management Accountants, 1994, [cit. 25. 8. 2015], http://www.imanet.org/docs/default-source/thought leadership /management control systems/implementing target costing.pdf

[3] Miles, L. D. Hodnotová analýza. ALFA n.p., Bratislava, 1971. ISBN 63-04571.

[4] Hosnedl, S. Systémové navrhování technických produktů. Západočeská univerzita v Plzni, Plzeň, 2012. ISBN 978-80-261-0125-3.

[5] Vozka, M., Kulhavý, O., Adam, L., Kozáková, Z. Konstrukční návrh s designérským řešením relaxačního transportního křesla. Semestrální projekt k předmětu systémové navrhování technických produktů, Západočeská univerzita v Plzni, Plzeň, 2011.

[6] Katedra makro a mikroekonomiky. Morfologická analýza [online] Žilina: Žilinská univerzita v Žilině, 2012, [cit. 25. 8. 2015], http://fria.fri.uniza.sk/ kmame/drupal/?q=system/files/Morfologick\%C3\%A $1 \%$ 20anal\%C3\%BDza.pdf 
[7] Trpák, L. a kol. Konstrukční návrh s designérským řešením průmylsové myčky součástí. Semestrální projekt k předmětu systémové navrhování technických produktů, Západočeská univerzita v PIzni, PIzeň, 2011. 